\title{
Mobile Counselling Online an Alternative Counselling Guidance System For Millennial Era Student
}

\author{
Eni Fariyatul Fahyuni ${ }^{1 *}$, Cindy Taurusta ${ }^{2}$, Retno Tri Hariastuti ${ }^{3}$, Adi Bandono ${ }^{4}$, Abdul \\ Muhid ${ }^{5}$ (D) \\ 1,2, Universitas Muhammadiyah Sidoarjo, Indonesia \\ ${ }^{3}$ Universitas Negeri Surabaya, Indonesia \\ ${ }^{4}$ Sekolah Tinggi Teknologi Angkatan Laut, Indonesia \\ ${ }^{5}$ Universitas Islam Negeri Sunan Ampel Surabaya, Indonesia \\ e-mail:eni.fariyatul@umsida.ac.id
}

\section{A R T I C L E I N F O}

Article history:

Received June 28, 2021

Revised June 30, 2021

Accepted July 28, 2021

Available online August 25, 2021

\section{Kata Kunci:}

Bimbingan konseling online,

android, self-efikasi

\section{Keywords:}

Online counseling guidance,

android, self-efficacy

DOI:

http://dx.doi.org/10.23887/jet.v5 i3.36191

\section{A B S T R A C T}

During the COVID-19 pandemic, there is a shortage of counseling guidance services, so students have difficulty consulting with teachers. This study aims to analyze the counseling service system during the COVID-19 pandemic on the introduction of potential and preparation of learning strategies for middle and high school students in the Sidoarjo district. This research design is a mixed-method with quantitative and qualitative approaches using exploratory factor analysis, and further research and development (R\&D) is carried out to produce products in the form of online counseling guidance services. The qualitative exploratory factor analysis results revealed various problems experienced and needed by students during the COVID-19 pandemic. Quantitatively showing eight forms of guidance and counseling services, strengthening skills with the highest score of 0.999 affected increasing self-efficacy and achievement motivation. The findings of this study indicate that online counseling services are very much needed to recognize potential and problems. The online counseling guidance service developed must meet three factors: understanding the potential for effective learning, developing and developing learning strategies, and building internal and external motivation. The innovation of online counseling guidance services must consider the factors of convenience, convenience, and user confidentiality that are adaptive, flexible, and unlimited in the millennial era.

This is an open access article under the $\underline{C C B Y-S A}$ license.

Copyright (C) 2021 by Author. Published by Universitas Pendidikan Ganesha.

\begin{abstract}
A B S T R A K sehingga siswa mengalami kesulitan Ketika melakukan konsultasi kepada guru. siswa SMP dan SMA di kabupaten Sidoarjo. Desain penelitian ini adalah mixedeksploratif dan selanjutnya dilakukan penelitian pengembangan $(R \& D)$ untuk menghasilkan produk berupa layanan bimbingan konseling online. Hasil analisis faktor eksploratif kualitatif mengungkapkan berbagai permasalahan yang dialami dibutuhkan siswa di masa pandemic COVID-19, sedangkan secara kuantitatif strengthening 0,999 tertinggi pengaruhnya pada peningkatan self efficacy dan motivasi berprestasi. Temuan penelitian ini menunjukkan layanan bimbingan konseling online sangat dibutuhkan untuk mengenal potensi dan masalah memenuhi tiga faktor yakni. memahamkan potensi belajar menyusun dan mengembangkan strategi belajar efektif, membangun motivasi internal dan eksternal. Inovasi layanan bimbingan konseling online harus mempertimbangkan faktor kemudahan, kenyamanan, dan kerahasiaan pengguna yang adaptif, fleksibel dan tanpa batas di era millennial.
\end{abstract}


of counselling guidance services in junior and senior high school in Sidoarjo regency, which cannot hold optimally. Due to the COVID-19 pandemic, students limited to consulting with counsellors at school. Another problem is the lack of use of counselling guidance instruments that applied to students. There are counsellor test tools, including learning potential tests, colour blind tests, multiple intelligence tests. Students need these various test to recognize their potential to develop learning strategies according to their characteristics. Counselling guidance occupy an essential role for students in improving academic, personal, social, intellectual and value aspects (Kadafi et al., 2021; Xia et al., 2021). Counselling guidance services, especially on the application of test with students' understanding of learning styles \& multiple intelligences, proved effective in improving student achievement (Wilson et al., 2020)(Drummond et al., 2021). With the implementation of restrictions on studying in schools during the current COVID-19 pandemic, it becomes an obstacle for students to study with counsellors to check their potential and learning difficulties. Counselling guidance at face-to-face have not been optimal, as long as these services identify student learning potential. For this reason, educators must recognize and understand the potential of students (Yaumi et al., 2018; Alilateh, A., \& Widyantoro, 2019). One of the services androids that an application has proven to be cost-effective, user-friendly, provides flexibility and ease of access (Malhotra et al., 2020; Guabassi \& Bousalem, 2018). Current counselling guidance must recognize the development of information technology so that it is easily accessible and utilized by users (Bastemur \& Bastemur, 2015; Putri, 2020).

The current development of the information technology field is undoubtedly an alternative solution where the current outbreak of the COVID-19 pandemic impacts school closures nationwide (Bayles et al., 2021; Zhang et al., 2021). It involves the realm of home-based learning, especially in terms of student study time, mostly done at home, by maximizing the use of the internet as a learning media during the COVID-19 pandemic (Lim et al., 2021; Tang et al., 2021; Yulia, 2020). The impact of school closures and distance learning shows that female students experience negative emotions such as fear, panic, and despair than male students who are more optimistic about facing the pandemic (Karasmanaki \& Tsantopoulos, 2021; Storch et al., 2021). The impact of the COVID-19 pandemic has triggered new mental disorders for some people, especially for those who have a mental illness and previous health problems (Stoecklin et al., 2020; Storch et al., 2021). Child development is greatly affected by the COVID-19 pandemic. For this reason, professionals, researchers, parents, teachers, and all those responsible must strive to provide health security for students. Therefore, the COVID-19 emphasizes the urgent need for theory development, policy adaptation and preventive measures to solve the various problems (Katz et al., 2020; Shah et al., 2020). Furthemore, the spread of the coronavirus has dramatically affected the mental health development of students in schools about distance learning patterns by forgetting the habits of interaction and student community in schools so that school closures and the transition to distance learning (Karasmanaki \& Tsantopoulos, 2021; Lim et al., 2021). The Counselling guidanceonline that make it easier for students to recognize their learning potential will significantly assist students in understanding their learning difficulties during the COVID-19 pandemic. By recognizing its learning potential, students will learn by recognizing and compiling effects according to the characteristics studied.

The innovation of developing mobile counselling online supports the local government program in Sidoarjo district as a "Smart City" that successfully integrates various applications to support the community's optimization. The various successes that Sidoarjo regency has achieved must be balanced with the development of digital technology, especially in education, to maximize learning during the COVID-19 pandemic. The novelty of mobile counselling online (MCO) facilitate student learning potential to learning process. This MCO innovation service is straightforward to use on unlimited student smartphones. MCO identifies learning potential. There are colour blind tests, learning style tests and multiple intelligence tests designed through smartphones. The application contains test results and features consultation with a competent counsellor and psychologist. For this reason, digital-based counselling can provide accessible students to access and conduct counselling guidance to help students face various problems (Bousalem, 2018; Prihandoko et al., 2020). The results showed that Islamic counselling effectively reduces anxiety in the face of the COVID-19 pandemic. In addition, the results of correlation analysis using Spearman's Rank show that there is a correlation between attention and anxiety (Kadafi et al., 2021). Counselling guidance which so far has only been done face-to-face, along with the times, must begin to change based on digital to meet service needs for students. Android is a smartphone revolution signifying technology that facilitates communication facilities for its users (Mesters et al., 2017; Roy et al., 2020). Android has paved the way for the smartphone revolution in technological advances. Use of cellular of mobile media tools and social media for active learner participation in the learning process (Narayan et al., 2019; Malhotra et al., 2020). Digital media expands students' opportunities to explore, collaborate, connect, reflect and share knowledge in an online environment (Blaschke \& Hase, 2019; Rafique et al., 2021). Communication via the internet has become an inseparable part of the teaching process (Madleňák, 2015; Wilde \& Hsu, 2019).

Digital-based online counselling guidance during the COVID-19 pandemic can build students' selfconfidence and achievement motivation. For this reason, teachers need to know and understand the potential of their students so that the learning process is carried out optimally (Peura et al., 2021; PharmD et al., 2020). 
Counselling guidance of digital-based information technology can adaptively various information wherever, whenever and with whom they can learn (Bastemur \& Bastemur, 2015; Guabassi \& Bousalem, 2018; Prihandoko et al., 2020). Thus, MCO must be packaged in an adaptive manner that provides convenience, comfort, and user privacy that students can access without distance and time limits. MCO includes learning potential tests, colour blindness tests, and multiple intelligence tests. The various test tools were available at the MCO, which developed aim to introduce students to their learning potential to build learning strategies according to their characteristics.

The urgency of this study is to analizing counseline online an alternative counselling guidance system for millennial era student during the COVID-19 pandemic. This research aims to analizing a prototype in the form of an application platform that supports counselling guidanceto increase self-efficacy and achievement motivation of junior and senior high school students during the COVID-19 pandemic. The prominent role of educators is to improve students' skills in managing their learning. MCO provides convenience, comfort, and privacy for its users. MCO facilitates students to recognize and understand their learning potential to help students' learning difficulties and limitations during the COVID-19 pandemic. Adaptive MCO is used by students without limits using only smartphones; students can easily access information, conduct counselling guidance tests and conduct consultations with the counsellors they want. Therefore, it is necessary to innovate digital-based counselling guidance during the COVID-19 pandemic to build students' self-efficacy and achievement motivation. Self-motivation is essential for lifelong education. Therefore, the counsellor must be able to strengthen personal development. Counselling guidance services must recognize student their potential that the learning process can optimally.

\section{METHOD}

This research uses a mixed-method with a quantitative approach using exploratory factor analysis to identify the most dominant influence variable from several variables that exist in the indicators of the implementation of counselling guidance system their effect on increasing self-efficacy and achievement motivation of junior and senior high school students in Sidoarjo Regency. Quantitative data support the mixed method in this study, namely by identifying the most dominant ( 8 items of counselling guidance), including; 1 ) personal problem counselling, 2) peer counselling and social community problems, 3) academic counselling, 4) family problems, 5) career and future life, 6) talent and interest learning, 7) process learning strategy, 8) strengthening skills. The qualitative research data was analyzed to reveal various student problems in depth by conducting interviews, observations and documentation in focus group discussions (FGD) involving supervisors, parents, principals and counsellors (Patton, 2015). The next step is to make a prototype of online counselling guidance. The last stage is to formulate and develop MCO according to the needs and context of junior and senior high school in Sidoarjo Regency, referring to the Dick and Carey model, which is a development model developed through a systems approach (Dick, W dan Carey, 2009). The learning system model developed by Dick, Carey \& Carey consists of several components that need to be done to design a broader and adaptive counselling service activity design.

The research process covering several steps, starting qualitatively with analysis to reveal various student problems and quantitatively aiming to measure the influence of counselling guidance services on each student. with the various methods carried out, it can be a needs analysis for online counselling services that are appropriate and needed by students in the millennial era. The subjects in this study were 120 junior and senior high school in Sidoarjo Regency. The considerations for determining the school in this study include a) willingness to cooperate with supervisors at the Education Office, b) willingness of school principals to collaborate in analizing guidance counseling online, c) enthusiasm and motivation of teachers to improve the quality counselling guidance in schools, d) the COVID-19 pandemic conditions impact the limitations of implementing face-to-face counselling and guidance services, and d) school locations facilitate collaborative communication so that products can be produced according to the needs and conditions of schools. The determination of these ten schools was based on purposive sampling by considering the readiness of the school on the completeness of existing infrastructure supported by a digitally literate teacher and student resources.

Table 2. Criteria for scoring

\begin{tabular}{cc}
\hline Score & Description \\
\hline 1 & Very dissatisfied \\
2 & Less dissatisfied \\
3 & Quite dissatisfied \\
4 & Satisfied \\
5 & Very satisfied \\
\hline
\end{tabular}


Questionnaires are distributed in distributed links through various social media such as Twitter, Facebook, and email lists. The instrument has developed by the researcher refers to the indicators of the functions and roles of counselling guidance services. The validity of the qualitative data in the research above, it was carried out through several stages, including; 1) initial test of data by extending time, ending of persistence in research, triangulation, and discussion with colleagues, 2) transferability of the application of research results to the sample population taken, 3) audit of the entire research process to research 4) confirmability test to test the results of research by from the beginning to the end of the process (Cresswell, 2014). The survey collect student information related to individual, social, career and learning problems that can affect students' self-efficacy and learning motivation (Golonka \& Makara-studzi, 2019). For this reason, counselors in schools need to help students recognize their various learning potentials (Peura et al., 2021).

The results of the exploratory factor analysis were further confirmed by qualitative analysis to reveal various student problems that require handling or type of counselling guidance that are needed to increase student' self-efficacy, achievements and motivations, especially during the COVID-19 pandemic. Before designing prototype for MCO, this research conduct focus group discussion with supervisors, principals and the counselling teacher to determine the understanding and readiness of educational institutions. Based on exploratory factor analysis with quantitative and qualitative data obtained, a prototype formulated to developed into a product in the form of an online counselling service model application according to the needs and current technological developments following the characteristics and context of the school.

\section{RESULT AND DISCUSSION}

\section{Result}

Today's development of information technology demands a change in the counselling guidance system that can be flexible using internet access For this reason, Android-based online Counselling guidance services are needed to facilitate their students' needs. The results of previous studies found much online counselling guidance, but services that first introduced the potential to help maximize student learning strategies. The novelty of this research is the innovation of online mobile counselling services (MCO), which introduces students' potential so that they can help students develop effective learning strategies according to their characteristics.

MCO developed a variety of test tools that can help students understand their learning potential and help students develop and recognise effective learning strategies according to themselves. the novelty of MCO provides unlimited convenience and services with students using their respective smartphones. MCO have the quality of security, privacy and convenience that provide broad access and ease of use. In addition to loading some test tools and the results, MCO will be sent automatically to the user. MCO is also equipped with a room consultation feature with counsellors or psychologists that users can choose students. MCO prototypes that was developed to facilitate complete services for students with various features that make it easy for its users;
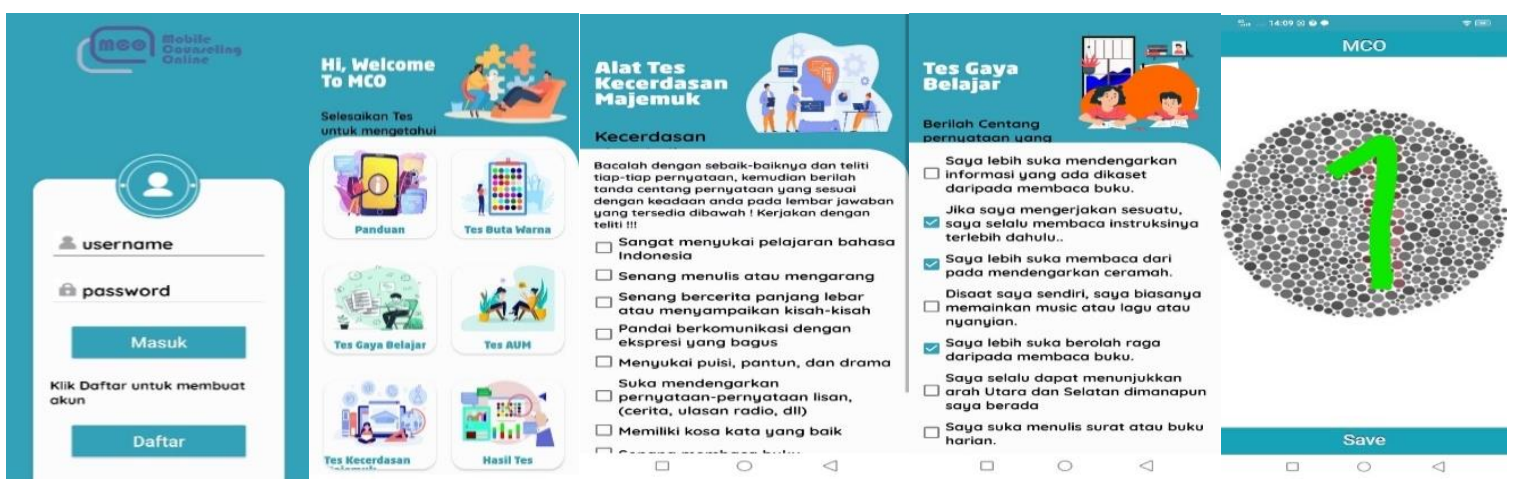

Figure 1. The innovation of online mobile counselling services (MCO)

Person's self-confidence will greatly help individuals develop their best abilities to achieve optimal performance. Motivation is also one of the essential factors to achieve optimal academic achievement. For this reason, it is necessary to innovate digital-based online counselling guidance during the COVID-19 pandemic to help students build self-efficacy. The following are the analysis results on the SPSS program for exploratory factor analysis showing eight indicator items for the online counselling program on a feasible prototype and can be continued. Based on the study results, the self-potential is essential for students to answer the problem 
according to their characteristics. Every student has different characteristics and types of learning from the visual learning style, auditory and kinesthetic. For this reason, counsellors need to design learning strategies for each individual differently, so students need to understand their conditions to be able to design effective learning strategies in the future. The rotated matrix above show that the eight factors of online counselling guidance needed by students to help improve self-efficacy and achievement motivation are grouped into three factors that are favoured and most needed by students. Influential group 1, students need understanding skills for their survival in the future, influential group 2, related to individual internal motivation problems, and influential group 3 , related to external factors and their learning environment. There are questionnaire items that have no effect or are needed by students, career and futures, which will then be deleted so that the supporting factors needed to apply online counselling guidance become seven indicators needed. This is also emphasized in figure 2.

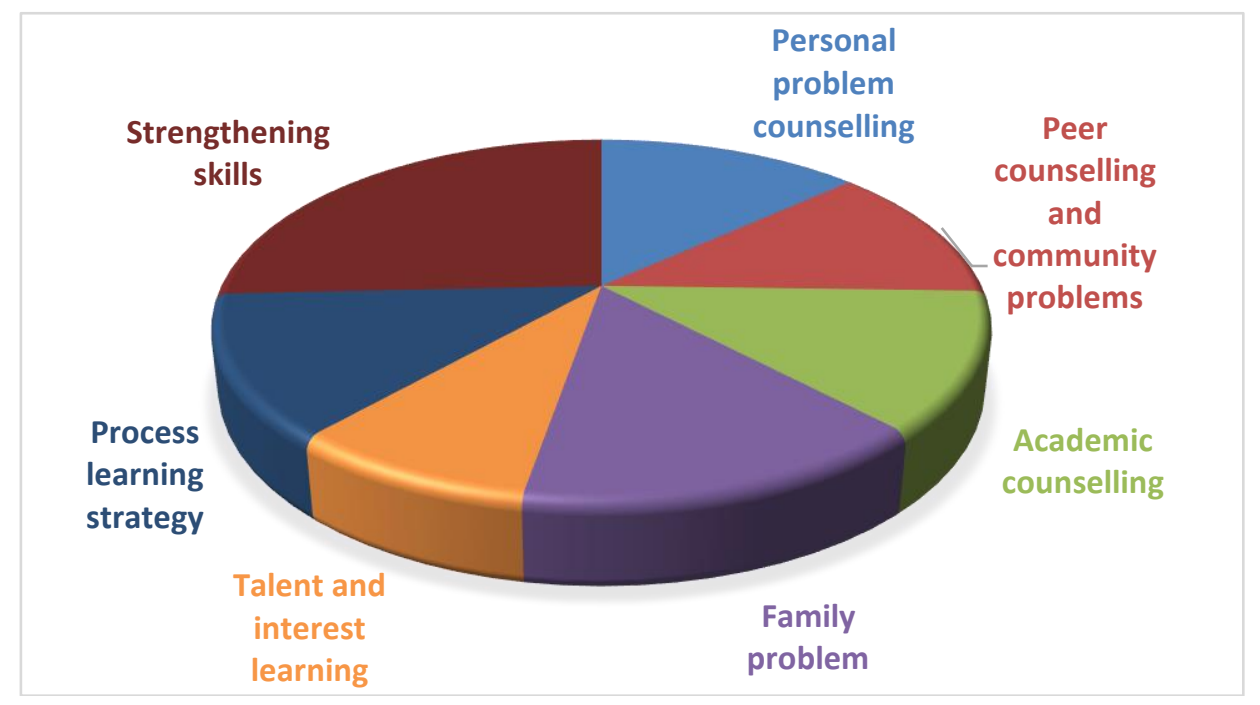

Figure 2. The functions and roles of counseling guidance

Based on the results of focus group discussion involving supervisors, principals and school counsellors indicated that counselling guidance an essential role in helping introduce students to their potential, understanding students' favourite college entrance strategies from within and outside the country and so on. Based on quantitative data showed that counselling services effectively increased self-efficacy for actively involved students, increasing their understanding of planning and preparing for careers after completing their studies and increasing student achievement. There is a linear relationship between self-efficacy and achievement motivation. Students with high self-confidence tend to have high achievement motivation and vice versa. Educators can use the pedagogy challenge to design active learning by utilizing digital media-based learning.

\section{Discussion}

By referring to current technological developments and the characteristics of their students, the guidance of counselling must adapt to the current context needed by students. The guidance of counselling online with MCO developed challenge and opportunity for students to maximize counselling and guidance services that students in schools rarely do. So far, most students perceive Counselling guidancein schools if they have problems. Counselling guidance in implementation are misguided so that it is necessary to straighten the form of service to its students. Student in junior and senior high school students in the millennial era are very familiar with using a communication tool called android (Roy et al., 2020; Rafique et al., 2021) in the form of a smartphone with various complete features in it (Narayan et al., 2019). With the development of digital technology today, it is easier and more accessible for students to connect to unlimited communication teacherstudent interaction equipped with internet support facilities (Pennings et al., 2018; Blaschke \& Hase, 2019; Malhotra et al., 2020). With the use of technology in learning can facilitate student learning according to student characteristics

Every student has different characteristics and types of learning styles (Lwande et al., 2021; Rasheed \& Wahid, 2021). There are three kinds of learning styles, but each student's percentage is not the same, starting from the visual learning style, auditory and kinesthetic (Costa et al., 2020; Sari, 2014). The quality of teachers and inappropriate methods are causing the low quality of education. Teachers tend to use the same method for each student. This teaching strategy certainly cannot accommodate every student's needs with various uniqueness and different learning styles. Therefore, it is necessary to apply a learning style test to understand 
each student's learning style (Dantas \& Cunha, 2020; Mashurwati, 2018). Innovations learning settings that prioritize holistic multi-sensory so that each individual is facilitated with the services provided (Sajnani \& Mayor, 2020).

MCO's support research results that online counselling guidance proven to improve student learning achievement, students capable of problem-solving, and adapt to their new environment \& conditions (Fahyuni et al., 2020; Gozali, 2020; Haryani, 2018; Hernawati \& Al., 2018; Koper, 2014; Satyawan et al., 2021). Counselors should guarantee the privacy of each client to help students faced their problems (Liston \& Geary, 2015; Zainudin, 2018). For this reason, the innovations developed must be able to create and maintain learning settings that prioritize holistic multi-sensory so that each individual is facilitated with the services provided (Sajnani \& Mayor, 2020; Fahyuni et al., 2021). Counselors ensure the privacy of client, faced their problems (Liston \& Geary, 2015; Peura et al., 2021; Zainudin, 2018).

Cybercounselling have many advantages because they involve using electronic media to ensure the confidentiality of their clients. However, online long-distance innovations must consider design, instruction and delivery techniques that pay attention to aesthetic elements. MCO's support research results that online counselling guidance proven to improve student learning achievement, students capable of problem-solving, and adapt to their new environment \& conditions (Fahyuni et al., 2020; Gozali, 2020; Haryani, 2018; Hernawati \& Al., 2018; Koper, 2014; Satyawan et al., 2021). Counselors should guarantee the privacy of each client (Zainudin, 2018) to help students faced their problems (Liston \& Geary, 2015). For this reason, the innovations developed must be able to create and maintain learning settings that prioritize holistic multi-sensory so that each individual is facilitated with the services provided (Sajnani \& Mayor, 2020; Fahyuni et al., 2021).

Motivation is a form of student achievement to be able to optimize their potential. One of the internal factors that influence achievement motivation is self-efficacy. Providing optimal counselling guidance implementing effective learning strategies. Thus, it can provide maximum learning services for students (Nasir et al., 2021). The effectiveness of MCO significant the increase in the value of their learning outcomes, students are on time in submitting assignments. Students are more confident in doing the assignments given by the teacher. Students currently need digital-based online counselling guidance during the COVID-19 pandemic to build their confidence. The results show that someone who has low self-efficacy tends to have difficulty completing tasks and problems, in contrast to those who have high self-efficacy, tend to be more adaptable and have strong selfconfidence in their problems (Wilde \& Hsu, 2019). Self-confidence can help individuals best abilities. Selfefficacy and teachers incorporating changes in student behaviour time by time (Peura et al., 2021). Self-efficacy helps students understand and recognize their potential future career preparations (Alfaiz et al., 2021). In this research, the innovation of mobile online counseling services (MCO) can be used by teachers as online counseling services for students.

\section{CONCLUSION}

Pre-existing online counselling guidance centred on counselling on various psychological problems faced by its clients. The MCO service facilitates understanding of students' potential and helps students develop effective learning strategies. The difference MCO provides Counselling guidanceservices that students can do independently using smartphones that guarantee client confidentiality and provide a consultation room for counsellors and psychologists that students can choose as they wish. The MCO presented adapts to the needs of students.This finding significantly helps the world of education improve the quality of learning and implement clear policies in implementing optimal online counselling services for junior and senior high school students.

\section{REFERENCES}

Alfaiz, A., Hidayat, H., Yandri, H., Tina, A., Sari, L., Sendayu, F. S., Suarja, S., \& Arjoni, A. (2021). Identification of Perceived Self-Efficacy to Predict Student's Awareness in Career Readiness. Islamic Guidance and Counseling Journal, 4. https://doi.org/0000-0003-1226-0443.

Alilateh, A., \& Widyantoro, A. (2019). The Effectiveness of Using Multiple Intelligence Activities in Listening Comprehension and Improving Students' Interest. LingTera, 6(2), 111-118. https://doi.org/10.21831/1t.v6i2.10625.

Bastemur, S., \& Bastemur, E. (2015). Technology Based Counseling: Perspectives of Turkish Counselors. Procedia - Social and Behavioral Sciences, 176(1998), 431-438. https://doi.org/10.1016/j.sbspro.2015.01.493.

Bayles, J., Peterson, A. D., Pitts, S. J., Bian, H., Burkholder, S., Hegde, A. V., \& Stage, V. C. (2021). FoodBased Science, Technology, Engineering, Arts, and Mathematics (STEAM) Learning Activities May 
Reduce Decline in Preschoolers' Skin Carotenoid Status. Journal of Nutrition Education and Behavior, 53(4). https://doi.org/10.1016/j.jneb.2020.10.017.

Blaschke, L. M., \& Hase, S. (2019). Heutagogy and Digital Media Networks: Setting Students on the Path to Lifelong Learning. Pacific Journal of Technology Enhanced Learning, 1(1), 1-14. https://doi.org/10.24135/pjtel.v1i1.1.

Bousalem, Z. et al. (2018). Science Direct Personalized Adaptive Content System for Context-Aware Ubiquitous Learning. Procedia Computer Science, 127, 444-453. https://doi.org/10.1016/j.procs.2018.01.142.

Chan, H. C. Y., \& Chan, L. (2018). Smart Library and Smart Campus. Journal of Service Science and Management, 11(06), 543-564. https://doi.org/10.4236/jssm.2018.116037.

Costa, R. D., Souza, G. F., Valentim, R. A. M., \& Castro, T. B. (2020). The Theory of Learning Styles Applied to Distance Learning. Cognitive Systems Research, 64. https://doi.org/10.1016/j.cogsys.2020.08.004.

Cresswell, J. W. (2014). Research Design. Qualitative Approaches, Quantitative and Mixed Methods. Publication, (Fourth Edi). Sage.

Dantas, L. A., \& Cunha, A. (2020). An Integrative Debate on Learning Styles and the Learning Process. Social Sciences \& Humanities Open, 2(1). https://doi.org/10.1016/j.ssaho.2020.100017.

Dick, W dan Carey, L. (2009). The Systematic Design of Instruction. Fifth Edition. New Jersey: Pearson Education Inc.

Drummond, D., Kirby, A. N., Gamston, C. E., Westrick, S., \& Saunders, J. (2021). Impact of Interdisciplinary Education on Pharmacy Student Knowledge and Comfort with Counseling on Drug-Nutrient Interactions. Currents in Pharmacy Teaching and Learning, 13(4). https://doi.org/10.1016/j.cptl.2020.11.007.

Fahyuni, E. ., Akbar, D., Hadi, N., \& Haris, M. I. (2020). Model Aplikasi Cybercounseling Islami Berbasis Website untuk Meningkatkan Self-Regulated Learning Siswa SMA. Inovasi Teknologi Pendidikan, 7(1), 93-104. https://doi.org/10.21831/jitp.v7i1.34225.

Fahyuni, E. ., Fauziyah, Y., Rindaningsih, I., \& Shoolihah, R. A. (2021). Pendampingan Konselor Sekolah pada Pengenalan Potensi Belajar Siswa di MTs Darussalam Kabupaten Sidoarjo. Dedication: Jurnal Pengabdian Masyarakat, 5(1), 15-26. https://doi.org/10.31537/dedication.v5i1.435.

Garad, A., Al-Ansi, A. M., \& Qamari, I. N. (2021). The Role of E-Learning Infrastructure and Cognitive Competence in Distance Learning Effectiveness during the Covid-19 Pandemic. Cakrawala Pendidikan, 40(1). https://doi.org/10.21831/cp.v40i1.33474.

Golonka, K., \& Makara-studzi, M. (2019). Self-Efficacy as a Moderator between Stress and Professional Burnout in Firefighters. https://doi.org/10.3390/ijerph16020183.

Gozali, A. (2020). Bimbingan dan Konseling Berbasis Teknologi Informasi pada Masa PSBB ( Pembatasan Sosial Berskala Besar ). Jurnal Bimbingan Konseling Pendidikan Islam Coution: Journal of Counseling and Education Layanan, 1(2), 36-49. https://doi.org/10.47453/coution.v1i2.117.

Guabassi, E., \& Bousalem, et al. (2018). Personalized Adaptive Content System for Context-Aware Ubiquitous Learning. Procedia Computer Science, 127, 444-453. https://doi.org/10.1016/j.procs.2018.01.142.

Haryani, et al. (2018). Improvement of Metacognitive Skills and Students' Reasoning Ability through ProblemBased Learning. Journal of Physics: Conference Series, 493-499. https://iopscience.iop.org/article/10.1088/1742-6596/983/1/012174.

Hernawati, L., \& Al., S. et. (2018). The Effectiveness of Cyber Counseling Service to Enhance Student Performance in Statistics. 247(Iset), 302-306. https://doi.org/10.2991/iset-18.2018.63.

Kadafi, A., Alfaiz, A., Ramli, M., Asri, D. N., \& Finayanti, J. (2021). The Impact of Islamic Counseling Intervention towards Students' Mindfulness and Anxiety During the Covid-19 Pandemic. Islamic Guidance and Counseling Journal, 4(1), 55-66. https://doi.org/10.25217/igcj.v4i1.1018.

Karasmanaki, E., \& Tsantopoulos, G. (2021). Impacts of Social Distancing During COVID-19 Pandemic on the Daily Life of Forestry Students. Children and Youth Services Review, 120(December 2020), 105781. https://doi.org/10.1016/j.childyouth.2020.105781.

Katz, C., Priolo Filho, S. R., Korbin, J., Bérubé, A., Fouché, A., Haffejee, S., Kaawa-Mafigiri, D., Maguire-Jack, K., Muñoz, P., Spilsbury, J., Tarabulsy, G., Tiwari, A., Thembekile Levine, D., Truter, E., \& Varela, N. (2020). Child Maltreatment in the Time of the Covid-19 Pandemic: A Proposed Global Framework on Research, Policy and Practice. Child Abuse and Neglect, November, 1-14. https://doi.org/10.1016/j.chiabu.2020.104824.

Koper, R. (2014). Conditions for Effective Smart Learning Environments. Smart Learning Environments, 1(1), 1-17. https://doi.org/10.1186/s40561-014-0005-4.

Lim, M. T. C., Ramamurthy, M. B., Aishworiya, R., Rajgor, D. D., Tran, A. P., Hiriyur, P., Kunaseelan, S., Jabri, M., \& Goh, D. Y. T. (2021). School Closure During the Corona Virus Disease 2019 (Covid-19) Pandemic - Impact on Children's Sleep. Sleep Medicine, 78(January 2020), 108-114. https://doi.org/10.1016/j.sleep.2020.12.025. 
Liston, J., \& Geary, T. (2015). Evaluating a Guidance Counsellor Education Programme: The Methodological Complexities. Procedia - Social and Behavioral Sciences, 191(0), 1014-1018. https://doi.org/10.1016/j.sbspro.2015.04.650.

Lwande, C., Muchemi, L., \& Oboko, R. (2021). Identifying Learning Styles and Cognitive Traits in a Learning Management System. Heliyon, 7(8). https://doi.org/https://doi.org/10.1016/j.heliyon.2021.e07701.

Madleňák, R. et al. (2015). Designing a Social Network to Support E-learning Activities at the Department of Communications, University of Žilina. Procedia - Social and Behavioral Sciences, 176, 103-110. https://doi.org/10.1016/j.sbspro.2015.01.449.

Malhotra, R., Kumar, D., \& Gupta, D. P. (2020). An Android Application for Campus Information System. Procedia Computer Science, 172, 863-868. https://doi.org/10.1016/j.procs.2020.05.124.

Mashurwati, Y. (2018). Penerapan Inventory Tes Gaya Belajar Remaja dengan Aplikasi Google Form, Media Sosial, Serta Pengembangan Program Layanan Bimbingan dan Konseling Terkait. Jurnal EDUCATIO: Jurnal Pendidikan Indonesia, 4(1), 1. https://doi.org/10.29210/120182131.

Mesters, I., Keulen, H. M. va., de Vries, H., \& Brug, J. (2017). Counselor Competence for Telephone Motivation Interviewing Addressing Lifestyle Change Among Dutch Older Adults. Evaluation and Program Planning, 65(May), 47-53. https://doi.org/10.1016/j.evalprogplan.2017.06.005.

Narayan, V., Herrington, J., \& Cochrane, T. (2019). Design Principles for Heutagogical Learning: Implementing Student-Determined Learning with Mobile and Social Media Tools. Australasian Journal of Educational Technology, 35(3), 86-101. https://doi.org/10.14742/ajet.3974.

Nasir, J. A., Khan, O. S., \& Varlamis, I. (2021). Fake News Detection: A Hybrid CNN-RNN Based Deep Learning Approach. International Journal of Information Management Data Insights, 1(1), 100007. https://doi.org/10.1016/j.jjimei.2020.100007.

Pennings, H. J. M., Brekelmans, M., Sadler, P., Claessens, L. C. A., van der Want, A. C., \& van Tartwijk, J. (2018). Interpersonal Adaptation in Teacher-Student Interaction. Learning and Instruction, 55, 41-57. https://doi.org/10.1016/j.learninstruc.2017.09.005.

Peura, P., Aro, T., Räikkönen, E., Viholainen, H., Koponen, T., Usher, E. L., \& Aro, M. (2021). Trajectories of Change in Reading Self-Efficacy: A Longitudinal Analysis of Self-Efficacy and Its Sources. Contemporary Educational Psychology, 64(January). https://doi.org/10.1016/j.cedpsych.2021.101947.

PharmD, V. K., McAuley, J., \& PharmD, M. M. (2020). Naloxone Counseling: Confidence and Attitudes of Student Pharmacists After a Volunteer Syringe Exchange Experience. Currents in Pharmacy Teaching and Learning, 12(4). https://doi.org/10.1016/j.cptl.2019.12.027.

Prihandoko et al. (2020). The Development of Counseling Services Assisted by the Application of Go Couns to Develop Self-Esteem in Junior High Schools throughout Semarang. International Journal of Scientific and Technology Research, 9(4), 2903-2905.

Putri, V. D. (2020). Layanan Bimbingan dan Konseling Daring Selama Masa Pandemi COVID-19. Jurnal Bimbingan Konseling Pendidikan Islam, 1(2), 7-16. https://doi.org/10.47453/coution.v1i2.95.

Rafique, G. M., Mahmood, K., Warraich, N. F., \& Rehman, S. U. (2021). Readiness for Online Learning during Covid-19 Pandemic: A Survey of Pakistani LIS Students. The Journal of Academic Librarianship, 47(3), 102346. https://doi.org/10.1016/j.acalib.2021.102346.

Rasheed, F., \& Wahid, A. (2021). Learning Style Detection in E-Learning Systems Using Machine Learning Techniques. Expert Systems with Applications, 174. https://doi.org/10.1016/j.eswa.2021.114774.

Roy, A., Jas, D. S., Jaggi, G., \& Sharma, K. (2020). Android Malware Detection Based on Vulnerable Feature Aggregation. Procedia Computer $\quad$ Science, $173(2019), \quad 353$. https://doi.org/10.1016/j.procs.2020.06.040.

Sajnani, N., \& Mayor, C. et al. (2020). Aesthetic Presence: The Role of the Arts in the Education of Creative Arts Therapists in the Classroom and Online. Arts in Psychotherapy, 69(February), 101668. https://doi.org/10.1016/j.aip.2020.101668.

Sari, A. K. (2014). Analisis Karakteristik Gaya Belajar VAK (Visual, Auditorial, Kinestetik) Mahasiswa Pendidikan Informatika Angkatan 2014. Jurnal Ilmiah Edutic, 1(1), 1-12. https://doi.org/10.21107/edutic.v1i1.395.

Satyawan, I. M., Wahjoedi, \& Swadesi, I. K. I. (2021). The Effectiveness of Online Learning Methods During the Covid-19 Pandemic. Journal of Education Technology, 5(2), 191-199. https://doi.org/10.2991/assehr.k.210203.093.

Shah, K., Arfan, M., Mahariq, I., Ahmadian, A., Salahshour, S., \& Ferrara, M. (2020). Fractal-Fractional Mathematical Model Addressing the Situation of Corona Virus in Pakistan. Results in Physics, 19, 103560. https://doi.org/10.1016/j.rinp.2020.103560.

Stoecklin, S. B., Rolland, P., Silue, Y., Mailles, A., Campese, C., Simondon, A., Mechain, M., Meurice, L., Nguyen, M., Bassi, C., Yamani, E., Behillil, S., Ismael, S., Nguyen, D., Malvy, D., Lescure, F. X., Georges, S., Lazarus, C., Tabai, A., ... Levy-Bruhl, D. (2020). First Cases of Corona Virus Disease 
2019 (Covid-19) in France: Surveillance, Investigations, and Control Measures, January 2020. Eurosurveillance, 25(6), 2000094. https://doi.org/10.2807/1560-7917.ES.2020.25.6.2000094.

Storch, E. A., Sheu, J. C., \& Guzick, A. G. et al. (2021). Impact of the Covid-19 Pandemic on Exposure and Response Prevention Outcomes in Adults and Youth with Obsessive-Compulsive Disorder. Psychiatry Research, 295(October 2020), 113597. https://doi.org/10.1016/j.psychres.2020.113597.

Tang, Y. M., Chen, P. C., Law, K. M. Y., Wu, C. H., Lau, Y., Guan, J., He, D., \& Ho, G. T. S. (2021). Comparative Analysis of Student's Live Online Learning Readiness During the Coronavirus (Covid-19) Pandemic in the Higher Education Sector. Computers \& Education, 168, 104211. https://doi.org/10.1016/j.compedu.2021.104211.

Wilde, N., \& Hsu, A. (2019). The Influence of General Self-Efficacy on the Interpretation of Vicarious Experience Information within Online Learning. International Journal of Educational Technology in Higher Education, 16(1). https://doi.org/10.1186/s41239-019-0158-x.

Wilson, O. W. A. C. M. B., Papalia, Z., Duffey, M., \& Bopp, M. (2020). College Students' Experiences and Attitudes toward Physical Activity Counseling. The Journal for Nurse Practitioners, 16(8). https://doi.org/10.1016/j.nurpra.2020.06.006.

Xia, W., Li, H. C. W., Liang, T., Luo, Y., \& Ho, L. L. K. (2021). Structured Online Training for University Students to Deliver Peer-Led Addiction Counselling for Young Drug Abusers in China: Effect on Improving Knowledge, Attitude, Confidence, and Skills. Patient Education and Counseling. https://doi.org/10.1016/j.pec.2021.07.038.

Yaumi, M., Sirate, S. F. S., \& Patak, A. A. (2018). Investigating Multiple Intelligence-Based Instructions Approach on Performance Improvement of Indonesian Elementary Madrasah Teachers. SAGE Open, 8(4). https://doi.org/10.1177/2158244018809216.

Yulia. (2020). Online Learning to Prevent the Spread of Pandemic Corona Virus in Indonesia. Eternal (English Teaching Journal), 11(1). https://doi.org/https://doi.org/10.26877/eternal.v11i1.6068.

Zainudin, Z. N. et al. (2018). Client's Satisfaction in Face-to-Face Counselling and Cyber Counseling Approaches: A Comparison. International Journal of Academic Research in Business and Social Sciences, 8(3), 677-684. https://doi.org/10.6007/ijarbss/v8-i3/3992.

Zhang, H., Daim, T., \& Zhang, Y. (Peggy). (2021). Integrating Patent Analysis into Technology Roadmapping: A Latent Dirichlet Allocation Based Technology Assessment and Roadmapping in the Field of Blockchain. Technological Forecasting and Social Change, 167. https://doi.org/10.1016/j.techfore.2021.120729. 